month, has contributors that include Gene Likens, the discoverer of acid rain, Thomas Kunz, a top bat expert, and Robert Costanza, founder of the field of ecological economics. Its international advisory board includes Rita Colwell, former director of the USNational Science Foundation.

Critics interviewed by Nature were unwilling to speak on the record. But some believe that the project is over-complicated, and that much of its underlying technology - which still requires significant development — runs against the trend to distribute information in lightweight formats that can be accessed by cell phones or PDAs such as the BlackBerry. "If you have to rely on a high-bandwidth alwayson network environment, on devices with a lot of storage, you are pretty much going in the wrong direction," says one critic, an expert in Internet information systems. $\mathrm{He}$ is also unimpressed by the Digital Universe's concept of peer-reviewing material. "There's more than enough content on the web, even substantive content," he says. " $\mathrm{I}$ 'm not sure that generating new content is really a breakthrough."

There are also questions over the business model, in which revenue would largely come from selling high-speed Internet access, with half the profits fed back into the work. "It's an odd choice; that's a dying business," comments one observer familiar with the project, pointing out that in the future consumers will be unlikely to notice where their Internet access comes from. But he says he can't help being inspired by the idea. 'They're trying to package science in a way that has some of the glitz and entertainment appeal of television, but that is also complete and correct," he says. "They're not in it for the money; actually, they're trying to save the world."

Declan Butler

www.digitaluniverse.net

\title{
Senators seek cash to save US science
}

\section{WASHINGTON DC \\ The United States is losing \\ its scientific edge and needs billions of extra dollars to rekindle innovation, according to a bipartisan group of US senators.}

After years of growth in areassuch as biomedical research, funding at US science agencies is now mostly flat or decreasing, and critics charge that the nation's competitiveness will soon suffer. The senators' solution consists of three new bills that would dramatically increase the number of science teachers nationwide, boost funding for research, and increase tax breaks for industrial research and development.

"This is a basic problem that America faces and that everybody in the US Senate ought to be totally committed tosolving," said Senator Pete Domenici (Republican, New Mexico), unveiling the bills on 25 January. The other sponsors of the legislation are Democrats Jeff Bingaman (New Mexico) and Barbara Mikulski
(Maryland), and Republican Lamar Alexander (Tennessee). The legislation, collectively dubbed the Protecting America's Competitive Edge (PACE) Act, recommends spending US $\$ 9.5$ billion in the first year alone. That money would go towards hir ing some 10,000 science and maths teachers, creating a crash programme for advanced energy research, and boosting funding by $10 \%$ at agencies such as the National Science Foundation, the Department of Energy and the National Oceanic and Atmospheric Administration.

Over the long term, the PACE Act recommends doubling the budget of these and other research offices, as well as providing research tax credits for industry and incentives for students who take a bachelor's degree in science, maths or engineering. The legislation is an attempt to implement the recommendations made in a report by the National Academies, which was released last October and warned that other countries were threatening US scientific

dominance (see Nature 437, 1208; 2005).

Not surprisingly, science advocates were almost universally enthusiastic about the proposed legislation. "We're excited about it," says Gerald Wheeler, executive director of the National Science Teachers Association in Arlington, Virginia. "We're creating the engine that's going to get us out of this crisis."

But others are more cautious about the bills' prospects. Sam Rankin, president of the Coalition for National Science Funding in Washington DC, notes that the PACE Act would only recommend spending levels. Money for the initiative would have to be coaxed from congressional appropriators, who must also fund the US presence in Iraq and other government programmes. "Time will tell whether the rhetoric is backed up by the funding," Rankin says.

Geoff Brumfiel

Additional reporting by

Jacqueline Ruttimann 